\title{
Assessment of MODIS NPP algorithm-based estimates using soil fertility and forest inventory data in mixed hemiboreal forests
}

\author{
Mait Lang ${ }^{1,2, *}$, Raimo Kõlli ${ }^{3}$, Maris Nikopensius ${ }^{2}$, \\ Tiit Nilson ${ }^{1}$, Mathias Neumann ${ }^{4}$ and Adam Moreno ${ }^{5}$
}

Lang, M., Kõlli, R., Nikopensius, M., Nilson, T., Neumann, M., Moreno, A. 2017. Assessment of MODIS NPP algorithm-based estimates using soil fertility and forest inventory data in mixed hemiboreal forests. - Forestry Studies | Metsanduslikud Uurimused 66, 49-64. ISSN 1406-9954. Journal homepage: http:/ / mi.emu.ee/forestry. studies

\begin{abstract}
Optical remote sensing data-based estimates of terrestrial net primary production (NPP) are released by different projects using light use efficiency-type models. Although spatial resolution of the NPP data sets is still too coarse (500-1000 m) for single forest stands, regional monitoring of forest management and growth with 25-100 ha sampling units is feasible if the $\mathrm{NPP}_{\mathrm{SAT}}$ estimates are sensitive to forest growth differences depending on soil fertility in the area of interest. In this study, NPP estimates for 2,914 mixed forest class pixels (according to the MODIS land cover map) located in Estonia were (1) obtained from three different $\mathrm{NPP}_{\mathrm{SAT}}$ products, (2) calculated using an empirical soil potential phytoproductivity (SPP) model applied to a 1:10,000 soil map ( $\left.\mathrm{NPP}_{\mathrm{SPP}}\right)$, and (3) calculated using stem volume increment estimates given in a forest management inventory data base $\left(\mathrm{NPP}_{\mathrm{FIDB}}\right)$. A linear multiple regression model was then used to explore the relationships of $\mathrm{NPP}_{\mathrm{SAT}}$ with the proportion of coniferous forests, the $\mathrm{NPP}_{\mathrm{SPP}}$ and distance of the pixels from the Baltic Sea coast - the variables that have been found informative in previous studies. We found a positive moderate correlation $(0.57, p<0.001)$ between $\mathrm{NPP}_{\mathrm{SPP}}$ and $\mathrm{NPP}_{\mathrm{FIDB}}$. The local or downscaled meteorological data-based $\mathrm{NPP}_{\mathrm{SAT}}$ estimates were more consistent with the $\mathrm{NPP}_{\mathrm{SPP}}$ and $\mathrm{NPP}_{\mathrm{FIDB}}$, but the correlation with $\mathrm{NPP}_{\mathrm{SAT}}$ was weak and sometimes even negative. The range of NPP estimates in $\mathrm{NPP}_{\mathrm{SAT}}$ data sets was much narrower than the range of $\mathrm{NPP}_{\mathrm{SPP}}$ or $\mathrm{NPP}_{\mathrm{FIDB}}$. Errors in land cover maps and in estimates of absorbed photosynthetically active radiation were identified as the main reasons for $\mathrm{NPP}_{\mathrm{SAT}}$ inconsistencies.
\end{abstract}

Key words: soil potential phytoproductivity, forest inventory data, MODIS NPP, fAPAR, land cover maps.

Authors' addresses: ${ }^{1}$ Tartu Observatory, 61602 Tõravere, Tartu County, Estonia; ${ }^{2}$ Institute of Forestry and Rural Engineering, Estonian University of Life Sciences, Kreutzwaldi 5, 51014 Tartu, Estonia; ${ }^{3}$ Institute of Agricultural and Environmental Sciences, Estonian University of Life Sciences, Kreutzwaldi 5, 51014 Tartu, Estonia; ${ }^{4}$ Institute of Silviculture, Department of Forest and Soil Sciences, University of Natural Resources and Life Sciences, Vienna, Peter-Jordan-Str. 82, A-1190 Wien, Austria; ${ }^{5}$ NASA Ames Research Center, Mail Stop 204-14, Moffett Field, CA 94035-0001, USA; *e-mail: mait.lang@emu.ee 


\section{Introduction}

Productivity of forest ecosystems is monitored and estimated using terrestrial sampling e.g. in case of National Forest Inventories (Tomppo et al., 2010; GFOI, 2013; Bontemps \& Bouriaud, 2014) or forest growth monitoring networks (Sims et al., 2014; Kiviste et al., 2015), using airborne lidar (ALS) data (Kandare et al., 2017), process-based modelling (Liu et al., 1997), combining ALS data and climate data with process-based modelling (Härkönen et al., 2013) or using spaceborne measurements of absorbed photosynthetically active radiation (APAR) in light use efficiency models (Zhao et al., 2005) as an alternative to pure terrestrial sampling. The light use efficiency or (LUE)-type models estimate the gross primary production of photosynthesis (GPP) based on APAR, LUE, water vapour pressure deficit (VPD) and ambient air temperature. Net primary production (NPP) is calculated by substracting autotrophic respiration from the GPP. Such models are used routinely for terrestrial net primary production $\mathrm{NPP}_{\mathrm{SAT}}$ estimates based on global satellite measurements (Zhao et al., 2011). The estimates have been validated e.g. using eddy-covariance measurements from flux towers (Turner et al., 2006) and ground reference NPP (Olson et al., 2001). Locally at specific sites, however, the estimates may have large uncertainties due to errors in model parameters and assumptions (Zhao et al., 2005), coarse scale input data (Eenmäe et al., 2011) and errors in land cover maps (Quaife et al., 2008; Lang et al., 2013). Higher accuracy could be achieved by using local or downscaled meteorological data (Olofsson et al., 2007; Härkönen et al., 2010; Nilson et al., 2012; Neumann et al., 2016) and combining remote sensing data and sample plot-based forest inventory data (Härkönen et al., 2011).

The growth of plants is determined by soil fertility in addition to APAR and ambient conditions (Tooming, 1977). More fertile soil stipulates photosynthesis. Waring et al. (2006) showed that soil fertility at a coarse scale is strongly correlated with the multispectral enhanced vegetation index which is a good predictor for GPP (Schubert et al., 2012). Inclusion of soil data into global scale NPP estimation models is problematic due to generality and inconsistencies of the existing global soil databases e.g. the harmonized world soil database, HWSD (FAO et al., 2012). However, high quality soil maps can be a valuable data source for evaluation of spaceborne NPP estimates when information for soil productivity estimation is available in the soil data base, on the other hand, soil management (Kõlli \& Kanal, 2010) may benefit from satellite data-based yearly estimates of the NPP. Discrepancies between NPP $\mathrm{SAT}_{\mathrm{SA}}$ and the potential productivity of soil can be used for targeting the areas where the forest management practices have to be reviewed. Time series of the $\mathrm{NPP}_{\mathrm{SAT}}$ are found informative for tree mortality monitoring and predicting (Neumann et al., 2017). Regional monitoring systems e.g. sCASE (Stagakis et al., 2015) can be constructed to locate problematic areas based on $\mathrm{NPP}_{\mathrm{SAT}}$. A necessary prior for this type of monitoring application is the evaluation of relationships between $\mathrm{NPP}_{\mathrm{SAT}}$ estimates and soil productivity in the area of interest.

In this study, we analysed LUE-based estimates of $\mathrm{NPP}_{\mathrm{SAT}}$ to evaluate their possible applicability in a forest NPP monitoring system in Estonia. We were interested in finding the most critical error sources in the $\mathrm{NPP}_{\mathrm{SAT}}$ estimates that must be targeted in future research. The $\mathrm{NPP}_{\mathrm{SAT}}$ was calculated from GPP, if available, using a uniform NPP/GPP ratio to decrease uncertainties arising from leaf area index (LAI) estimates and averaged over observation period. To carry out the study, we constructed a GIS database where the elementary sampling unit (ESU) was a MODIS grid cell with the size of 50 ha. Considering that the mean forest stand size in Estonia is about 1.3 ha (Raudsaar et al., 2016) we used 
data from mixed forest class ESUs. Since there is only one flux tower in Estonia (Noe et al., 2015) where continuous measurements are done, we used the soil potential phytoproductivity (SPP) model of Kõlli (1988) applied to the database of a 1:10,000 soil map as an independent reference for the assessment of $\mathrm{NPP}_{\mathrm{SAT}}$. To each ESU we assigned also (1) tree species composition, site index and an estimate of NPP based on stem volume increment from a forest inventory database (FIDB) (2) an estimate of disturbed area and current forest land area from Landsat images-based map, (3) land cover class codes from MODIS land cover maps, (4) fraction of APAR (fAPAR) from MODIS and MERIS products that were used, and (5) distance from the Baltic Sea coast. We used regression modelling to analyse the relationships between the long term mean $\mathrm{NPP}_{\mathrm{SAT}}$ and the explanatory variables in the database.

\section{Material and Methods}

\section{Soils of Estonia}

Located in the transition area between continental and marine climates in mild and wet pedo-climatic conditions of the temperate zone, mixed forests are characteristic of the naturally developed areas of the Estonian land cover. In the course of intensified agricultural activity during the last two centuries the most productive soils (suitable for crop cultivation and grasslands) were turned into arable, pastured or hay-lands.

At present the forests cover approximately half of the Estonian land surface (Raudsaar et al., 2016). A remarkably large part $(36.9 \%)$ of forest soils form Histosols (classification system: IUSS (2014)), whereas among them sapric and fibric soil subdivisions in fens and bogs are dominating. The Gleysols form approximately $35.7 \%$ of forest soils, while half of them are characterized as eutric (calcareous) and a quarter as dystric. Also Histic Podzols belong to this wet (epigleyic) mineral soil group (forming $\sim 3 \%$ of forest soils). The share of automorphic mineral soils is only $24.3 \%$ of forest: subdivisions of Retisols (7.9\%), Cambisols (6.5\%) and Podzols (6.0\%) are dominating (Kõlli et al., 2009).

The dominating texture of forest soils is peat $(37 \%)$ and sand $(35 \%)$. The share of loams, which have the highest forest growing potential, is only $16 \%$ of the forest land. The share of loamy sands and clays is $9 \%$ and $3 \%$, respectively, of the forest land. With respect to moisture conditions $39 \%$ of forest soils are characterized as wet mineral (epigleyic), $37 \%$ - wet peaty (histic), $13 \%$ automorphic fresh, $9 \%$ - moist (endogleyic) and $2 \%-$ dry, aridic.

\section{Soil map and database}

The results of preliminary soil survey of Estonia from 1954 to 1980 are large scale $(1: 10,000)$ soil maps and the corresponding database (Mullakaardi, 2001). The map covers entire terrestrial territory $(43,432$ $\mathrm{km}^{2}$ ) of the Estonia. Later, these maps have been updated paying more attention to the fabric of humus profiles, particle size distribution, organic carbon and nitrogen content, and the main chemical and physical properties of topsoil. In 1998-2001 the large scale soil map of Estonia was digitised by E.O. Map Ltd for reproduction of hardcopies of the map. This soil map is the property of the Estonian Land Board (Mustamäe tee 51, 10621, Tallinn, Estonia). The database contains soil codes, formulae of soil texture and humus profiles, stoniness, soil quality and relative share of soil subtypes within complex soil polygons. The percentages were used as weights for the mean productivity for each soil polygon.

\section{Model of soil phytoproductivity}

For characterizing the SPP the pedo-ecological schema of normally developed mineral soils (i.e. soils which, at present, are not influenced by new sediments accumulation nor topsoil elimination) was used (see Figure 2 in Kõlli et al., 2004). This 
schema categorizes soils according to their pedo-ecological conditions. It is characterized by two scalars: (1) a vertical eightstage litho-genetic scalar from rendzina to podzols, which arranges soils on the basis of parent materials' properties, calcareousness, processes of soil functioning and site trophicity, and (2) a horizontal six-stage moisture scalar from aridic or well-aerated to permanently wet or reducing conditions. To estimate potential productivity for each soil in the soil map data base we used a simple model (Kõlli, 1988) which in principle is a look-up table relating the two scalars and above-ground SPP. No other input is required for the model.

The plant biomass measurement databased semi-empirical SPP model (Kõlli, 1988) was initially created for quantitative characterization of organic matter (organic carbon) flux throughout the soil, which started with litter fall on the surface and subsequent phytomass transfer into the soil. As litter fall depends on plant cover productivity, the long period mean annual SPP $\left(\mathrm{Mg} \mathrm{ha}^{-1} \mathrm{yr}^{-1}\right)$ for the main soil types had to be estimated. Two substantial aspects have to be mentioned: (1) soil productivity comprises not only the productivity of the plant cover (primary or phytomass productivity), but also the biomass productivity of meso- and microfauna, which is negative in relation to primary (phytomass) productivity, and (2) the mean annual SPP level was determined in relation to stabilized forest ecosystems when the tree storey has passed the fastest growing period, but the understory layers have stabilized. The forests in the phytomass sampling sites had (1) the stand relative density in the range of $0.6-0.8$, and (2) the mean age of stands in the range of $60-$ 100 years (Kõlli, 1988).

The above reveals that (1) in earlier growing periods of spruce, pine, birch, etc. forests the total annual SPP can be remarkably greater than estimated with our SPP model, and (2) the annual SPP is always smaller than the annual NPP (SPP < NPP), which is caused by secondary productivity and heterotrophic respiration (i.e. decay of attached dead branches) of the plant cover. Therefore the SPP may be treated as a persisted (or survived) NPP at the end of the vegetation period. However, we assume that SPP characterizes adequately the differences in productivity between different soil types.

\section{Estimation of soil potential NPP}

The SPP model was taken from Figure 3.2 in Kõlli (1988), digitized and converted into a $80 \times 80$ units lookup table. The lookup table was based on soil genetic and moisture coordinates which were also assigned for each soil patch in the soil database. The original SPP model was based mainly on empirical data from normally developed soils and estimates the potential aboveground phytoproductivity $\left(P_{\mathrm{SPP}}\right)$. For waterlogged Gleysols and thin Sapric Histosols $\left(\mathrm{M}^{\prime}\right)$ with characteristic horizons of the forest floor, raw-humus and peat indicating to stagnated growth conditions, an adjustment based on the thickness of these layers was applied

$P_{\mathrm{SPP}(\mathrm{G})}=P_{\mathrm{SPP}}-g\left(\mathrm{O}_{\mathrm{HOR}}-\overline{\mathrm{O}}_{\mathrm{HOR}}\right)$

where $O_{\text {HOR }}$ is the total thickness $(\mathrm{cm})$ of the layer of organic matter and peat, $g=$ $\left(P_{\mathrm{SPP}}(\mathrm{Go})-P_{\mathrm{SPP}}\left(\mathrm{M}^{\prime}\right)\right) / 40=0.12$ is a parameter based on $P_{\mathrm{SPP}}=12.9 \mathrm{Mg} \mathrm{ha}^{-1} \mathrm{yr}^{-1}$ for Mollic Gleysols (Go) and $8.2 \mathrm{Mg} \mathrm{ha}^{-1} \mathrm{yr}^{-1}$ for $\mathrm{M}^{\prime}$ soil and their $40 \mathrm{~cm}$ difference in $O_{\mathrm{HOR}}$, and $\bar{O}_{\text {HOR }}$ is the mean $O_{\text {HOR }}$ for each soil type in the soil database. An additional adjustment $P_{\mathrm{SPP}(\mathrm{GI})}=0.85 \times P_{\mathrm{SPP}(\mathrm{G})}$ was applied to Luvic Gleysols (GI) based on clay, sand or fine sand.

LUE-type models estimate the total product of photosynthesis, i.e. above and below-ground. We scaled $P_{\mathrm{SPP}} \times(1+0.2)=$ $N P P_{\text {SPP }}$ to add an estimate of below-ground NPP to the model of Kõlli (1988). The factor 1.2 corresponds to IPCC (2006) guidelines for mature stands in the temperate forest zone. The factor 1.2 here also counts 
for fine root turnover, since the SPP model includes litter fall which can be assumed similar to fine root turnover according Raich \& Nadelhoffer (1989).

\section{Forest management inventory database and calculation of stem volume increment-based NPP}

The forest management inventory database (FIDB) was obtained in March 2013 from the State Register for Accounting of Forest Resource (IDB, 2016). The FIDB records are yearly updated only for state forests and the age of the inventory records is usually not more than five years, whereas data for private forests may be outdated, since updates are not obligatory after disturbances including management. The FIDB consists of a 1:10,000 vector map of forest stands and a large set of stand specific inventory variables used for forest management planning issues. In this study, we used site fertility index $H_{100}$ (m; predicted height when forest is 100 years old) and tree species composition as descriptive variables and stem volume increment $i_{\mathrm{v}}$ $\left(\mathrm{m}^{3} \mathrm{ha}^{-1} \mathrm{yr}^{-1}\right)$ to estimate NPP. The $i_{\mathrm{v}}$ in the FIDB is used for forest management planning and is calculated with a model (Metsakorralduse, 2017) using forest age, stand relative density and $H_{100}$. The net primary production $N P P_{\mathrm{FIDB}}=i_{\mathrm{v}} \times B C E F i+2 \times m_{\mathrm{L}}$ for each forest stand was calculated by using the biomass conversion and expansion factor $B C E F i=0.6 \times(1+0.2)=0.72$ and yearly litter fall $m_{\mathrm{L}}$. The BCEF $i$ was derived from IPCC (2006) guidelines for mature stands in the temperate forest zone and includes also the below-ground fraction. The fine root turnover was assumed to be equal to litter fall according to Raich and Nadelhoffer (1989).

The yearly litter fall $m_{L}\left(\mathrm{~g} \mathrm{~m}^{-2} \mathrm{yr}^{-1}\right)$ was estimated with a temperature $(T)$ and precipitation $(S)$ driven model from Liu et al. (2004) for deciduous broadleaf forests and evergreen coniferous forests

$m_{\mathrm{L}(\mathrm{con})}=\exp (2.708+0.505 \times \ln (T+10)+0.24 \times \ln (S))$

where $T=5.1^{\circ} \mathrm{C}$ and $S=700 \mathrm{~mm} \mathrm{yr}^{-1}$ were used as climatological mean values for Estonia (Kliimaatlas, 1970).

\section{Satellite data-based NPP estimates}

Three data sources were used to obtain annual estimates of $\mathrm{NPP}_{\mathrm{SAT}}$. First was a Terra MODIS (Moderate-resolution Imaging Spectroradiometer) data-based GPP|NPP product (version 5.5) released by the $\mathrm{Nu}$ merical Terradynamic Simulation Group (NTSG; The University of Montana, USA). The GPP and NPP values are based on yearly reprocessed data to decrease the influence of missing data due to clouds (Zhao et al., 2011; Zhao et al., 2005). The second $\mathrm{NPP}_{\mathrm{SAT}}$ estimate was extracted from MODIS EURO product (Neumann et al., 2016) and was also based on Terra MODIS data but using downscaled European climate data (Moreno \& Hasenauer, 2016) instead of the global climate driver. The third productivity estimate was based on Envisat MERIS data and is described in more detail by Nilson et al. (2012) who developed a LUE-type model EST_PP. The EST_PP model was run using high spatial resolution meteorological data and a local land cover map (Nilson et al., 2012).

In this study we preferred the $\mathrm{NPP}_{\mathrm{SAT}}$ estimates derived directly from the GPP, if available, instead of using LAI-based autotrophic respiration-based $\mathrm{NPP}_{\mathrm{SAT}}$. A simple scaling with a uniform ratio was applied to avoid errors inherent in LAI estimates and combined effects of land cover map-based model parameters.

The EST_PP GPP and NTSG MODIS GPP were converted to NPP using the ratio of MODIS NPP/GPP=0.55 for mixed forests taken from Nilson et al. (2012). This factor is greater than that presented by Zhao et al. (2005) who show also a smaller NPP/GPP for deciduous broadleaf forests 
compared to evergreen coniferous forests. We also tested NPP/GPP ratio weighting with the share of coniferous trees according to the FIDB, since the share of coniferous stands in our 50 ha sampling units varies. The EST_PP-based NPP/GPP $=0.66$ was used for deciduous broadleaf forests and NPP/GPP $=0.45$ for evergreen coniferous forests (Table 2 in Nilson et al., 2012). In total we had five estimates of $\mathrm{NPP}_{\mathrm{SAT}}$ (Table 1) from the period of 2000-2012. Average value over the period of each $\mathrm{NPP}_{\mathrm{SAT}}$ estimate was used, since the soil fertility-based $N P P_{\text {SPP }}$ corresponds to a long term average value.

Table 1. Description of NPP and fAPAR estimates used in this study.

Tabel 1. Taimkatte primaarse produktsiooni ja fAPAR hinnangud.

\begin{tabular}{|c|c|}
\hline $\begin{array}{l}\text { Variable / } \\
\text { Tunnus }\end{array}$ & $\begin{array}{l}\text { Data source and description / } \\
\text { Kirjeldus ja viited }\end{array}$ \\
\hline$N P P_{\text {SPP }}$ & $\begin{array}{l}\text { Soil potential NPP based on the } \\
\text { soil map and model of Kõlli (1988) }\end{array}$ \\
\hline$N P P_{\text {FIDB }}$ & $\begin{array}{l}\text { Stemwood volume increment } \\
\text { scaled by the } B C E F i \text { plus an } \\
\text { estimate of litter and production } \\
\text { of fine roots }(2,3) \text { according to } \\
\text { tree species composition }\end{array}$ \\
\hline$N P P_{\text {NTSG_GPP }}$ & $\begin{array}{l}\text { NTSG MODIS GPP (Zhao et al., } \\
\text { 2011) scaled using } \\
\text { a } 0.55 \mathrm{NPP} / \mathrm{GPP} \text { ratio }\end{array}$ \\
\hline$N P P_{\mathrm{NTSG}}$ & NTSG MODIS NPP (Zhao et al., 2011) \\
\hline$N P P_{\text {EST_PP_GPP }}$ & $\begin{array}{l}\text { EST_PP MERIS GPP (Nilson et al., } \\
\text { 2012) scaled using } \\
\text { a } 0.55 \text { NPP/GPP ratio }\end{array}$ \\
\hline$N P P_{\text {EST_PP_GPP_sw }}$ & $\begin{array}{l}\text { EST_PP MERIS GPP (Nilson et al., } \\
\text { 2012) scaled using tree species' } \\
\text { weighted NPP/GPP ratio }\end{array}$ \\
\hline$N P P_{\text {EURO }}$ & $\begin{array}{l}\text { MODIS EURO NPP (Neumann et al., } \\
\text { 2016) }\end{array}$ \\
\hline$f A P A R_{M E}$ & $\begin{array}{l}\text { mean yearly (from April to } \\
\text { October) sum of MERIS fAPAR }\end{array}$ \\
\hline$f A P A R_{M O}$ & $\begin{array}{l}\text { mean yearly (from April to } \\
\text { October) sum of MODIS fAPAR }\end{array}$ \\
\hline
\end{tabular}

\section{Data analysis}

Data analysis was carried out in a grid similar to the Climate Modeling Grid used for MODIS products (Figure 1). The geographical coordinate system (latitude, longitude) was used. In Estonia the size of the grid pixels in a Cartesian coordinate system is about $1,000 \times 500 \mathrm{~m}$. Spatial queries in the GIS were carried out to assign mean attribute values from all input data sets to the grid pixels. Since the landscape in Estonia is heterogeneous with respect to the $1,000 \times 500 \mathrm{~m}$ sampling units and there are errors in raster data due to resampling in coordinate system transformation, only the pixels located at least $1 \mathrm{~km}$ inside forest patch borders were extracted. This was to decrease errors inherent from raster image resampling, gridding effects in MODIS images (Tan et al., 2006) and the influence of view geometry (Xin et al., 2013).

The FIDB stand map provides spatially continuous information on forests and analyses can be carried out using individual pixels of the MODIS grid (Figure 1) instead of aggregating the pixels by at least $0.066^{\circ}$ resolution as found appropriate for sample plot-based National Forest Inventory data by Moreno et al. (2016). To exclude pixels with outdated forest inventory data we used disturbance maps based on Landsat images (Urmas Peterson, Tartu Observatory, personal communication). The Landsat dataset covers the period of 1987-2013 with about a five-year interval.

For the analysis we extracted pixels located more than $30 \mathrm{~km}$ away from the Baltic Sea coast to avoid artefacts caused by the VPD in LUE-type models in the Baltic region (Eenmäe et al., 2011; Lang et al., 2013). Next, the pixels which had a forest inventory data cover less than $75 \%$ of their area were eliminated from the evaluation. Finally, by selecting the pixels with less than $10 \%$ of the pixel area disturbed since 2001 and after removing 84 outliers, the total number of mixed forest class pixels according to the MODIS land cover map (MCD12Q1, UMD (Type 2), year 2001) was 




Figure 1. A fragment of the MODIS grid showing borders of six sampling units. Each MODIS grid cell was assigned information from reference data sets.

Joonis 1. Igale vaatlusühikuna kasutatud MODIS võrgustiku pikslile arvutati puistute keskmised takseertunnused ja keskmine mullaviljakus. Taustal on valevärvi ortofoto.

2,914, which corresponds roughly to 1,340 $\mathrm{km}^{2}$.

The factor $c_{\mathrm{f}}=0.5 \mathrm{~g} \mathrm{C} \mathrm{g}^{-1}$ was used as the fraction of carbon in biomass for NPP and $N P P_{\mathrm{FIDB}}$ which were based on biomass estimates.

To analyse NPP and fAPAR estimates given in Table (1) we used a linear regression model

$y=a_{0}+a_{1} Z_{\mathrm{DAO}}+a_{2} N P P_{\mathrm{SPP}}+a_{3} K+\beta$,

where $a_{x}$ are parameters, $Z_{\mathrm{DAO}}$ indicates the global coarse spatial-scale meteorological data-caused longitudinal zones (Eenmäe et al., 2011) in NTSG MODIS NPP SAT $_{\text {esti- }}$ mates, $K(\%)$ is the percent of coniferous trees (forests) calculated from FIDB and $\beta$ is the error term. The value $Z_{\mathrm{DAO}}=2$ was used for central Estonia (longitude 24.4 $4^{\circ}$ $26.5^{\circ} \mathrm{E}$ ) and $Z_{\mathrm{DAO}}=3$ for the Eastern part of Estonia. The number of observations was 2,914 .

\section{Results and Discussion}

\section{Forest structure in the elementary sampling units}

When the MODIS grid cells were used as observations the interquartile ranges of forest age, canopy cover (describes stand density) and the share of coniferous forests were $37-58$ years, $53-70 \%$ and $31-69 \%$. In most of the ESU-s the mean age of forests is less than was in the sample forests used for the SPP model, but the difference is not large. For this analysis we selected mixed forest class pixels from $\mathrm{NPP}_{\mathrm{SAT}}$ datasets according to MODIS land cover map. According to the forest inventory data only half of the sample corresponds do the definition indicating problems in the MODIS land cover map.

\section{Ground data-based NPP estimates}

Soil data-based NPP estimates were first compared to the forest site index of the FIDB and $N P P_{\text {FIDB }}$ (Figures 2 and 3). As expected, the forest site index $H_{100}$ was 


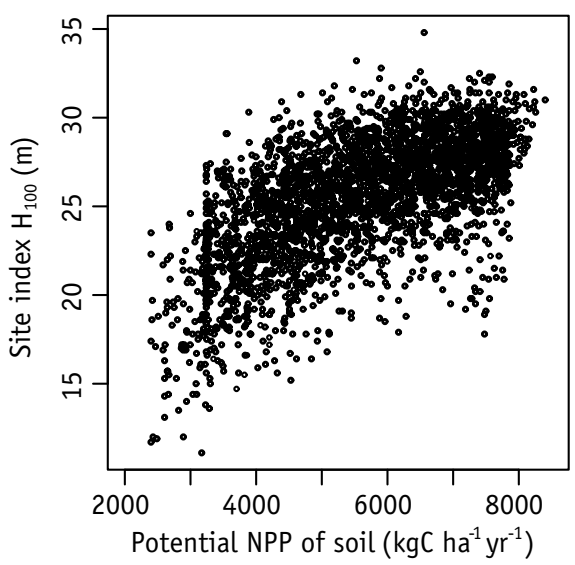

Figure 2. Forest inventory-based site fertility index and soil potential NPP.

Joonis 2. Boniteet ja mulla potentsiaalne fütoproduktiivsus.

positively correlated $(0.63, p<0.001)$ with the $N P P_{\text {SPP }}$ showing that the two terrestrial data sets are not conflicting. The $N P P_{\text {SPP }}$ described $28 \%$ of the wood volume increment-based NPP estimate in a simple linear regression model. The mean value of NPP $\mathrm{SPP}\left(5.6 \mathrm{tC} \mathrm{ha-1} \mathrm{yr}^{-1}\right)$ was greater $(p$ $<0.001$ ) than $N P P_{\text {FIDB }}$ (Table 2) and the interquartile range of $N P P_{\mathrm{SPP}}$ was also larger (2.34 $\left.\mathrm{tC} \mathrm{ha}^{-1} \mathrm{yr}^{-1}\right)$. It is not clear how well the factor 1.2 covered fine root production for $N P P_{\mathrm{SPP}}$. The mean value of fine root production as estimated with model of Liu et al. (2004) for the Estonia corresponded to $1.5 \mathrm{tC} \mathrm{ha}^{-1} \mathrm{yr}^{-1}$ which is similar to the mean value for temperate zone as reported by Finér et al. (2011) who show also a large variability of the estimate. Another reason for the difference is that we accounted only for the tree layer in $N P P_{\mathrm{FIDB}}$ ignoring forest understory (regrowth, bushes, grass, mosses and lichens). However, in dense forest stands the relative share of forest understory in the total biomass production is small (Varik et al., 2009). Discrepancies between $N P P_{\text {SPP }}$ and $N P P_{\text {FIDB }}$ are also caused by the underestimation of stem volume increment by the model used in forest management inventory according to a recent vali-

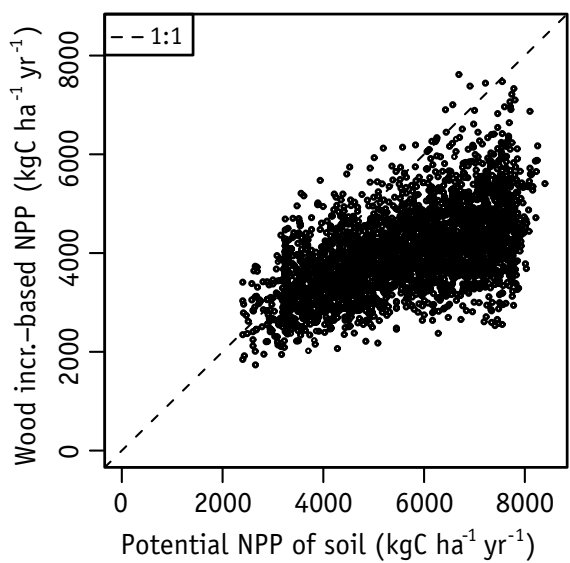

Figure 3. Wood volume increment-based NPP of trees and soil potential NPP.

Joonis 3. Tüvepuidu juurdekasvu järgi hinnatud puistu NPP ja mulla potentsiaalne fütoproduktiivsus.

dation on repeated measurements of the Estonian National Forest Inventory sample plots (Allan Sims 2017, The Estonian Environment Agency, personal communication). The correlation between $N P P_{\mathrm{SPP}}$ and $N P P_{\text {FIDB }}$ could also be improved by using stand-specific biomass expansion factors. However, the relationships provide enough evidence that $N P P_{\text {SPP }}$ can be used to evaluate LUE-type model-based NPP $\mathrm{SAT}_{\mathrm{SA}}$ estimates, since the soil map covers whole of Estonia and the SPP model was based on biomass sampling data including litter fall.

There was a characteristic lack of fit of the LUE-based $\mathrm{NPP}_{\mathrm{SAT}}$ along the soil fertility gradient (Figure 4a, 4b). To some extent the lack of fit can be related to fine root production which was assumed to be a constant proportion of above-ground NPP in $N P P_{\text {SPP. }}$ The estimates of fine root production vary with different methods (Yuan \& Chen, 2012a). The amount of fine roots depends on forest age and understory (Makkonen \& Helmisaari, 2001). In fertile middle-aged spruce stands fine root production can be $13 \%$ of the total NPP (Ostonen et al., 2005). Fine root production tends to increase with soil fertility (Yuan \& Chen, 2012b), but in less fertile soils plants 
have to invest relatively more of the total NPP in their root system (Vanninen \& Mäkelä, 1999). However, fine roots cannot explain the about three times smaller interquartile range of LUE-based $\mathrm{NPP}_{\mathrm{SAT}}$ estimates compared to $N P P_{\mathrm{SPP}}$ (Table 2).

\section{The influence of applied NPP/GPP ratio on the NPP $\mathbf{P A T}_{\mathrm{SAT}}$ estimates}

The small variability in the LUE-based $\mathrm{NPP}_{\mathrm{SAT}}$ of the sample can be caused to some extent by the constant NPP to GPP ratio that was used to calculate the NPP from GPP. This approach is similar to the production of global-scale LUE-based NPP estimates where one set of model parameters is used for the mixed forest class. In mixed forests, however, the NPP/GPP is related to the species composition and mainly to the ratio of evergreen coniferous and deciduous broadleaf tree species. Based on MODIS GPP and NPP estimates Zhao et al. (2005) give NPP/GPP $=0.35$ for deciduous broadleaf forests and 0.54 for evergreen coniferous forests. DeLucia et al. (2007) show that in the temperate climate zone the NPP/GPP ratio is just the opposite. The NPP/GPP ratio depends also on stand age (Mäkelä \& Valentine, 2001; Tang et al., 2014), however, considering the mean stand size of 1.3 ha in Estonia (Raudsaar et al., 2016) and the 50 ha observation units used in this study the age-dependent effects are probably not prevailing over the tree species-dependent influence on the NPP/GPP.

The share of coniferous forests was significant in the model (Eq. 4). By excluding $K$ from the model (Eq. 4) the variability described $\left(R^{2}\right)$ by the constant NPP/GPPbased NPP EST_PP_GPP decreased from 0.30 to 0.19 . When $K$ was used as the weight to convert the EST_PP GPP to NPP EST_PP_GPP_sw the model (Eq. 4) excluding $K$ still described $27 \%$ of variability in $N P P_{E S S_{-} P P_{-} G P P_{-} s w}$ and also the range of NPP values increased (Table $2)$. The reason here is negative correlation $(-0.47, p<0.001)$ between the share of evergreen coniferous forests in our individual observations and soil potential NPP. Poor soils in Estonia are usually dominated by

Table 2. Parameter estimates for the multiple linear regression model Equation (4). Dependent variables are described in Table (1). The IQR is the interquartile range of the NPP estimates. Statistically non-significant values are in italics.

Tabel 2. Regressioonmudeli võrrandi (4) parameetrite hinnangud. Statistiliselt mitteolulised väärtused on kursiivis. Funktsioontunnused on kirjeldatud tabelis (1). IQR on kvartiilhälve.

\begin{tabular}{|c|c|c|c|c|c|c|c|}
\hline \multirow{2}{*}{$\begin{array}{l}\text { Dependent variable / } \\
\text { Sõltuv muutuja }\end{array}$} & \multirow{2}{*}{$\begin{array}{c}\text { Mean / Keskväärtus } \\
\left(\mathrm{kg} \mathrm{C} \mathrm{ha-1} \mathrm{yr}^{-1}\right)\end{array}$} & \multirow[t]{2}{*}{$I Q R$} & \multicolumn{5}{|c|}{ Model parameters / Mudel parameetrid } \\
\hline & & & $a_{0}$ & $a_{1}$ & $a_{2}$ & $a_{3}$ & $R^{2}$ \\
\hline$N P P_{\mathrm{FIDB}}$ & 4020 & 1124 & $235^{*}$ & 293 & 0.29000 & -2.17 & 0.32 \\
\hline$N P P_{\text {NTSG_GPP }}$ & 5512 & 362 & 5869 & -215 & 0.00570 & 2.97 & 0.21 \\
\hline$N P P_{\mathrm{NTSG}}$ & 5451 & 491 & 6171 & -371 & -0.00630 & 4.88 & 0.43 \\
\hline$N P P_{\mathrm{NTSG}}$ & 5451 & 491 & 5234 & - & -0.01100 & 5.56 & 0.16 \\
\hline$N P P_{\text {EST_PP_GPP }}$ & 4429 & 171 & 4358 & 20 & 0.02200 & -2.06 & 0.30 ** \\
\hline$N P P_{\text {EST_PP_GPP_SW }}$ & 4472 & 749 & 3306 & 85 & 0.17000 & - & 0.27 \\
\hline$N P P_{\text {EURO }}$ & 5260 & 302 & 4878 & 107 & -0.02300 & 4.91 & 0.39 \\
\hline$f A P A R_{M E}$ & - & - & 175 & -1.35 & 0.00049 & -0.042 & 0.14 \\
\hline$f A P A R_{M O}$ & - & - & 154 & 1.68 & 0.00004 & 0.032 & 0.03 \\
\hline
\end{tabular}

* the NPP FID for parameter estimation was without the litter and fine roots to avoid artificial correlation with the species composition variable $(K)$ used also as weight for litter model equations $(2,3)$.

** $R^{2}=0.19$ when the share of coniferous forests was excluded from the model argument list. 

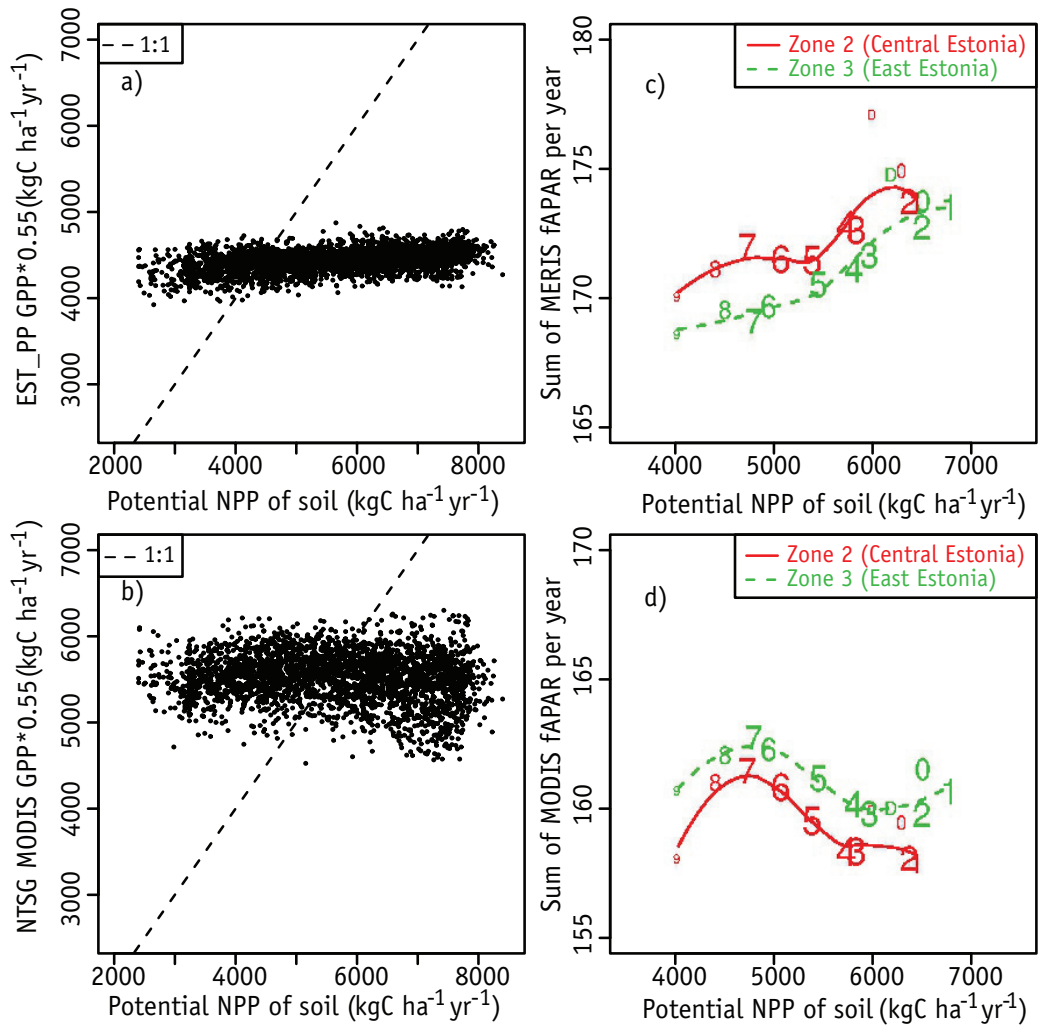

Figure 4. LUE-based $N P P_{S A T}$ estimates ( $a$, b; see Table 1) depend more on $f A P A R(\mathrm{c}, \mathrm{d})$ than on the potential NPP of the soil. Numeric symbols correspond to the proportion of evergreen coniferous forests, "D" stands for $100 \%$ deciduous broadleaf forest class, and symbol size corresponds to the number of pixels.

Joonis 4. LUE-mudelil põhinevad NPP hinnangud ei reageeri oluliselt mulla viljakusele Eestis $(a, b)$, vaid neid mõjutab pigem mudeli sisendis olev fAPAR $(c, d)$. Numbersümbolid näitavad okaspuude osakaalu, "D" tähistab 100\% lehtpuumetsa klassi. Sümbolid on skaleeritud vastavalt pikslite arvule klassis.

Scots pine except in lowland fens where black alder and downy birch are the prevailing species. With the increase in soil fertility the share of Norway spruce increases on account of Scots pine and deciduous dominated mixed forests are in majority (Adermann, 2009). A weak negative correlation $(-0.31, p<0.001)$ exists also between the share of coniferous forests and stem volume increment estimates in the pixels.

\section{Evaluation of the NPP $\mathrm{SAT}_{\mathrm{ST}}$ estimates}

By using the parameters from Table (2) of the model Eq. (4) for $N P P_{\mathrm{FIDB}}$ as a reference the LUE-based NPP estimates can be analysed. Similarly to $N P P_{\mathrm{FIDB}}$ the EST_PP NPP estimates had a positive correlation with the longitude of pixel position as well as with the SPP, but correlation with $K$ was negative. The NPP estimate $\left(N P P_{\text {NTSG }}\right)$ from the standard global product had a negative correlation with the pixel position longitude which is a similar relationship to that found by Eenmäe et al. (2011) for the MODIS product. The correlation of $N P P_{\text {NTSG }}$ with $N P P_{\text {SPP }}$ was not significant and correlation between $N P P_{\mathrm{NTSG}}$ and $K$ was positive which is the opposite of the correlation found with $N P P_{\mathrm{FIDB}}$. By excluding the variable $Z_{\mathrm{DAO}}$ from the model, only $16 \%$ of variation of $N P P_{\text {NTSG }}$ was described compared to the initial $43 \%$ (Table 2). 
The MODIS data and downscaled meteorological data-based $N P P_{\text {EURO }}$ had a positive correlation with the pixel location longitude similarly to $N P P_{\text {FIDB }}$ which indicates successful use of European downscaled climate data by Neumann et al. (2016). Although the relationship with $N P P_{\mathrm{SPP}}$ was negative and significant in the model, $N P P_{\text {SPP }}$ described only $2 \%$ of the variation in $N P P_{\text {EURo. }}$ For comparison: when only $K$ was included in the model (Eq. 4) still 32\% of variation in $N P P_{\text {EURO }}$ was described, but the correlation was positive, i.e. opposite to the correlation between $N P P_{\mathrm{FIDB}}$ and $N P P_{\text {SPP }}$ and also between $N P P_{\text {SPP }}$ and EST PP-based NPP. NPP $P_{\text {EURO }}$ was calculated from the GPP by subtracting autotrophic respiration and growth losses based on the LAI (Neumann et al., 2016). The problems must therefore be looked for in LAI estimates or in fAPAR which strongly correlated $\left(R^{2}>0.43\right)$ with the derived NPP $\mathrm{SAT}_{\mathrm{S}}$ in all the corresponding Envisat MERIS and Terra MODIS data-based estimates.

\section{The estimates of the fraction of absorbed} photosynthetically active radiation

The model (Eq. 4) described $14 \%$ of $f A P A R_{M E}$ but only $3 \%$ of $f A P A R_{M O}$ variability (Table $2)$. The relationship between $N P P_{\mathrm{SPP}}$ and $f A P A R_{M E}$ was close to linear, but with $f A P A R_{M O}$ the relationship was nonlinear with the shape somewhat depending on the proportion of evergreen coniferous forests in the pixels (Figure 4c, 4d). It also appears that fAPAR from MERIS and MODIS have the opposite correlation with pixel location longitude (Table 2) and also with the share of evergreen coniferous forests in the pixels. However, the models describe only a small part of fAPAR variability and a fAPAR targeted study based on an independent reference measurement of fAPAR is required to explain the co-relations. For example, Kuusk et al. (2016) found that landscape albedo from MODIS data is underestimated due to small clouds which can have similar effect on the fAPAR measured using coarse spatial resolution sensors.

\section{Land cover maps as the source of errors}

D'Odorico et al. (2014) found that the differences between MODIS and MERIS fAPAR products may be related to land cover maps used for determining radiative transfer model parameters from look-up tables or the assumptions made for the estimation procedure. Errors in land cover types influence GPP estimates through fAPAR estimates. Wrong light use efficiency factors and growth limiting functions influence also NPP estimates. For example, for $N P P_{\text {NTSG }}$ and MODIS fAPAR different land cover maps are used - Type 2 and Type 3 .

We extracted a set of pixels with a big productivity potential $\left(N P P_{\mathrm{SPP}}>5 \mathrm{t} \mathrm{C} \mathrm{ha}^{-1}\right.$ $\mathrm{yr}^{-1}$ ) and a small yearly sum of $f A P A R_{M O}$ and found that the mixed forests according to the MODIS Type 2 land cover map belong to the class "Evergreen Needleleaf forest" in the Type 3 land cover map and according to the ground truth data from the FIDB there are deciduous broadleafdominated forests. With another query a set of pixels with the biggest $f A P A R_{M O}$ was extracted along the $N P P_{\mathrm{SPP}}$ range. In the Type 3 land cover map the pixels belonged to the "Evergreen Broadleaf forest" class which does not exist in Estonia. According to orthophotos and the FIDB the pixels were from pine stands in transitional sphagnum bogs or coniferous dominated forests. There is no mixed forest class in the Type 3 land cover map. The 2,914 mixed forest class pixels in the Type 2 land cover map were distributed between the "Evergreen Broadleaf forest" (172), "Deciduous Broadleaf forest" (454) and "Evergreen Needleleaf forest" $(2,288)$ classes in the Type 3 land cover map. While the EST_PP NPP estimates were based on local land cover maps and were in agreement with the FIDB data and SPP, similar improvements can be expected in the MODIS GPP|NPP when thematically more accurate land cover data is used. 


\section{Conclusions}

The Estonian soil map and forest management inventory database provided valuable information for evaluation of satellite data-based NPP estimates. The two terrestrial estimates showed smaller NPP for poor soils and greater NPP for fertile soils. This was in contrast to the LUE-type model estimated NPP that had mean value similar to the terrestrial estimates, whereas almost no reaction to change in soil fertility in Estonia. The main reason for the lack of fit was apparently the estimate of fraction of absorbed photosynthetically active radiation which is the main input variable of LUE-type NPP models. A validation of the Type 2 land cover map showed that classification of $50 \%$ of the mixed forest class pixels is not correct. Land cover maps are used in the estimation of fAPAR and NPP. Improved land cover maps following the classification schema of the current global maps can be constructed regionally by local institutions that have access to high resolution data (both thematically and spatially). Subsets of the global land cover maps could then be updated to obtain more consistent fAPAR, GPP and NPP estimates locally and globally. We also see a need for improved methods for the fAPAR estimation for hemiboreal mixed forests.

Acknowledgements. This work is part of the projects 'The carbon dynamics in Estonian forests affected by sustainable management' (Estonian Ministry of Education and Research grant no. IUT21-4) and FORMIT ('Enhancing the FORest MITigation potential of European Forests') receiving funding from the European Union Seventh Framework Programme under grant agreement no. 311970. The MERIS data were provided by the ESA and MODIS GPP/NPP and FAPAR data by NASA and the NTSG. We thank four anonymous reviewers for helping to improve the manuscript.

\section{References}

Adermann, V. 2009. Forests of Estonia. (Eesti Metsad 2008). Metsakaitse- ja Metsauuenduskeskus, Tallinn. (In Estonian).

Bontemps, J.D., Bouriaud, O. 2014. Predictive approaches to forest site productivity: recent trends, challenges and future perspectives. Forestry, 87, 109-128.

DeLucia, E.H., Drake, J.E., Thomas, R.B., GonzalezMeler, M. 2007. Forest carbon use efficiency: Is respiration a constant fraction of gross primary production? - Global Change Biology, 13, 1157-1167.

D’Odorico, P., Gonsamo, A., Pinty, B., Gobron, N., Coops, N., Mendez, E., Schaepman, M.E. 2014. Intercomparison of fraction of absorbed photosynthetically active radiation products derived from satellite data over Europe. Remote Sensing of Environment, 142, 141-154.

Eenmäe, A., Nilson, T., Lang, M. 2011. A note on meteorological variables related trends in the MODIS NPP product for Estonia. - Forestry Studies / Metsanduslikud Uurimused, 55, 60-63.

FAO, IIASA, ISRIC, ISS-CAS, JRC. 2012. Harmonized World Soil Database (version 1.2). FAO, Rome, Italy and IIASA, Laxenburg, Austria.

Finér, L., Ohashi, M., Noguchi, K., Hirano, Y. 2011. Fine root production and turnover in forest ecosystems in relation to stand and environmental characteristics. - Forest Ecology and Management, 262, 2008-2023.

GFOI. 2013. Integrating remote-sensing and groundbased observations for estimation of emissions and removals of greenhouse gases in forests: Methods and Guidance from the Global Forest Observations Initiative: Pub: Group on Earth Observations, Geneva, Switzerland, 2014. ISBN 978-92-990047-4-6.

Härkönen, S., Lehtonen, A., Eerikäinen, K., Peltoniemi, M., Mäkelä, A. 2011. Estimating forest carbon fluxes for large regions based on processbased modelling, NFI data and Landsat satellite images. - Forest Ecology and Management, 262, 2364-2377.

Härkönen, S., Pulkkinen, M., Duursma, R., Mäkelä, A. 2010. Estimating annual GPP, NPP and stem growth in Finland using summary models. - Forest Ecology and Management, 259, 524-533.

Härkönen, S., Tokola, T., Packalén, P., Korhonen, L., Mäkelä, A. 2013. Predicting forest growth based on airborne light detection and ranging data, climate data, and a simplified processbased model. - Canadian Journal of Forest Research, 43, 364-375. 
IDB. 2016. State register for accounting of forest resource. (Metsaressursi arvestuse riikliku registri põhimäärus). - Riigi Teataja, RT I, 12.01.2016, 2. (In Estonian).

IPCC. 2006. 2006 IPCC Guidelines for National Greenhouse Gas Inventories. - Eggelston. S., Buendia. L., Miwa. K., Ngara. T., Tanabe. K (eds.). Hayama: Institute of Global Environmental Strategies (IGES). Volume 4: Agriculture, Forestry and Other Land Use.

IUSS Working Group WRB. 2014. World Reference Base for Soil Resources 2014. International soil classification system for naming soils and creating legends for soil maps. World Soil Resources Reports No. 106. FAO, Rome.

Kandare, K., Ørka, H.O., Dalponte, M., Næsset, E., Gobakken, T. 2017. Individual tree crown approach for predicting site index in boreal forests using airborne laser scanning and hyperspectral data. - International Journal of Applied Earth Observation and Geoinformation, 60, 72-82.

Kiviste, A., Hordo, M., Kangur, A., Kardakov, A., Laarmann, D., Lilleleht, A., Metslaid, S., Sims, A., Korjus, H. 2015. Monitoring and modeling of forest ecosystems: the Estonian Network of Forest Research Plots. - Forestry Studies / Metsanduslikud Uurimused, 62, 26-38.

Kliimaatlas. 1970. Climate data in Estonia (Eesti NSV kliimaatlas). Eesti NSV Hüdrometeoroloogia teenistuse valitsus. Tallinn.

Kõlli, R. 1988. Phytoproductivity of Estonian soils in forest land. - Почвоведение, 4, 96-107. (In Russian).

Kõlli, R., Asi, E., Köster, T. 2004. Organic carbon pools in Estonian forest soils. - Baltic Forestry, 10(1), 19-26.

Kõlli, R., Ellermäe, O., Köster, T., Lemetti, I., Asi, E., Kauer, K. 2009. Stocks of organic carbon in Estonian soils. - Estonian Journal of Earth Sciences, 58, 95-108.

Kõlli, R., Kanal, A. 2010. The management and protection of soil cover: an ecosystem approach. - Forestry Studies / Metsanduslikud Uurimused, 53, 25-34.

Kuusk, A., Kuusk, J., Lang, M. 2016. Albedo of the forested landscape at the SMEAR-Estonia research station. - Baltic Forestry, 22(2), 390-395.

Lang, M., Traškovs, A., Gulbe, L. 2013. Assessment of NTSG MODIS NPP product for forests in Kurzeme region, Latvia. - Forestry Studies / Metsanduslikud Uurimused, 58, 26-36.

Liu, C., Westman, C.J., Berg, B., Kutsch, W., Wang, G.Z., Man, R., Ilvesniemi, H. 2004. Variation in litterfall-climate relationships between coniferous and broadleaf forests in Eurasia. Global Ecology and Biogeography, 13, 105-114.
Liu, J., Chen, J.M., Cihlar, J., Park, W.M. 1997. A process-based boreal ecosystem productivity simulator using remote sensing inputs. - Remote Sensing of Environment, 62, 158-175.

Mäkelä, A., Valentine, H.T. 2001. The ratio of NPP to GPP: evidence of change over the course of stand development. - Tree Physiology, 21, 1015-1030.

Makkonen, K., Helmisaari, H.S. 2001. Fine root biomass and production in Scots pine stands in relation to stand age. - Tree Physiology, 21, 193-198.

Metsakorralduse. 2017. Forest inventory act. (Metsa korraldamise juhend). - RT I, 22.02. 2017, 11. (In Estonian).

Moreno, A., Hasenauer, H. 2016. Spatial downscaling of European climate data. - International Journal of Climatology, 36, 1444-1458.

Moreno, M., Neumann, M., Hasenauer, H. 2016. Optimal resolution for linking remotely sensed and forest inventory data in Europe. - Remote Sensing of Environment, 183, 109-119.

Mullakaardi. 2001. The fine-scale map of Estonian soils. (Vabariigi digitaalse suuremõõtkavalise mullastiku kaardi seletuskiri). Maa-amet, Tallinn. [WWW document]. - http:// geoportaal.maaamet.ee/est/ Andmed-jakaardid/Mullastiku-kaart-p33.html [Accessed 16 April 2016]. (In Estonian).

Neumann, M., Moreno, A., Thurnher, C., Mues, V., Härkönen, S., Mura, M., Bouriaud, O., Lang, M., Cardellini, G., Thivolle-Cazat, A., Bronisz, K., Merganic, J., Alberdi, I., Astrup, R., Mohren, F., Zhao, M., Hasenauer, H. 2016. Creating a regional MODIS satellite-driven net primary production dataset for European forests. - Remote Sensing, 8(7), 554, doi:10.3390/rs8070554.

Neumann, M., Mues, V., Moreno, A., Hasenauer, H., Seidl, R. 2017. Climate variability drives recent tree mortality in Europe. Global Change Biology, 00, 1-10, https://doi.org/10.1111/ gcb.13724 (In press).

Nilson, T., Rennel, M., Luhamaa, A., Hordo, M., Olesk, A., Lang, M. 2012. MERIS GPP/NPP product for Estonia: I. Algorithm and preliminary results of simulation. - Forestry Studies / Metsanduslikud Uurimused, 56, 56-78.

Noe, S.M., Niinemets, Ü., Krasnova, A., Krasnov, D., Motallebi, A., Kängsepp, V., Jõgiste, K., Hõrrak, U., Komsaare, K., Mirme, S., Vana, M., Tammet, H., Bäck, J., Vesala, T., Kulmala, M., Petäjä, T., Kangur, A. 2015. SMEAR Estonia: Perspectives of a large-scale forest ecosystem atmosphere research infrastructure. - Forestry Studies / Metsanduslikud Uurimused, 63, 56-84. 
Olofsson, P., Eklundh, L., Lagergren, F., Jonsson, P., Lindroth, A. 2007. Estimating net primary production for Scandinavian forests using data from Terra/MODIS. - Advances in Space Research, 39, 125-130.

Olson, R.J., Johnson, K.R., Zheng, D.L., Scurlock, J.M.O. 2001. Global and regional ecosystem modeling: Databases of model drivers and validation measurements. Oakridge Laboratory: Oak Ridge, TN, USA.

Ostonen, I., Lõhmus, K., Pajuste, K. 2005. Fine root biomass, production and its proportion of NPP in a fertile middle-aged Norway spruce forest: Comparison of soil core and ingrowth core methods. - Forest Ecology and Management, 212, 264-277.

Quaife, T., Quegan, S., Disney, M., Lewis, P., Lomas, M., Woodward F.I. 2008. Impact of land cover uncertainties on estimates of biospheric carbon fluxes. - Global Biogeochemical Cycles, 22, 1-12.

Raich, J.W., Nadelhoffer, K.J. 1989. Belowground carbon allocation in forest ecosystems: global trends. - Ecology, 70, 1346-1354.

Raudsaar, M., Pärt, E., Adermann, V. 2016. Forest resources. In: Yearbook Forest 2014. Tallinn, Keskkonnaagentuur. 1-61.

Schubert, P., Lagergren, F., Aurela, M., Christensen, T., Grelle, A., Heliasz, M., Klemedtsson, L., Lindroth, A., Pilegaard, K., Vesala, T., Eklundh, L. 2012. Modeling GPP in the Nordic forest landscape with MODIS time series data comparison with the MODIS GPP product. Remote Sensing of Environment, 126, 136-147.

Sims, A., Mändma, R., Laarmann, D., Korjus, H. 2014. Assessment of tree mortality on the Estonian Network of Forest Research Plots. Forestry Studies / Metsanduslikud Uurimused, 60, 57-68.

Stagakis, S., Markos, N., Vanikiotis, T., Tzotsos, A., Sykioti, O., Kyparissis, A. 2015. sCASE: A primary productivity monitoring system for the forests of North Pindus National Park (Epirus, Greece). - European Journal of Remote Sensing, 48, 223-243.

Tan, B., Woodcock, C.E, Hu, J., Zhang, P., Ozdogan, M., Huang, D., Yang, W., Knyazikhin,Y., Myneni, R.B. 2006. The impact of gridding artifacts on the local spatial properties of MODIS data: Implications for validation, compositing, and band-to-band registration across resolutions. Remote Sensing of Environment, 105, 98-114.

Tang, J., Luyssaert, S., Richardson, A.D., Kutsch, W., Janssens, I.A. 2014. Steeper declines in forest photosynthesis than respiration explain age-driven decreases in forest growth. - Proceedings of the National Academy of Sciences, $111,8856-8860$.
Tomppo, E., Gschwantner, T., Lawrence, M., McRoberts, R. 2010. National Forest Inventories: Pathways for common reporting. Springer: Berlin, Germany.

Tooming, H. 1977. Solar radiation and yield formation. Gidrometeoizdat, Leningrad, Russia.

Turner, D.P., Ritts, W.D., Cohen, W.B., Gower, S.T., Running, S.W., Zhao, M., Costa, M.H., Kirschbaum, A.A., Ham, J.M., Saleska, S.R., Ahl, D.E. 2006. Evaluation of MODIS NPP and GPP products across multiple biomes. Remote Sensing of Environment, 102, 282-292.

Vanninen, P., Mäkelä, A. 1999. Fine root biomass of Scots pine stands differing in age and soil fertility in southern Finland. - Tree Physiology, 19, 823-830.

Varik, M., Aosaar, J., Uri, V. 2009. Biomass production in silver birch stands in Oxalis site type. - Forestry Studies / Metsanduslikud Uurimused, 51, 5-16.

Waring, R.H., Milner K.S., Jolly, W.M., Phillips, L., McWethy, D. 2006. Assessment of site index and forest growth capacity across the Pacific and Inland Northwest U.S.A. with a MODIS satellite-derived vegetation index. - Forest Ecology and Management, 228, 285-291.

Xin, Q., Olofsson, P., Zhu, Z., Tan, B., Woodcock, C.E. 2013. Toward near real-time monitoring of forest disturbance by fusion of MODIS and Landsat data. - Remote Sensing of Environment, 135, 234-247.

Yuan, Z.Y., Chen, H.Y.H. 2012a. Indirect methods produce higher estimates of fine root production and turnover rates than direct methods. - PLoS ONE 7(11): e48989. doi:10.1371/journal.pone. 004898.

Yuan, Z.Y., Chen, H.Y.H. 2012b. A global analysis of fine root production as affected by soil nitrogen and phosphorus. - Proceedings of the Royal Society B: Biological Sciences, 279, 3796-3802.

Zhao, M., Heinsch, F.A., Nemani, R.R., Running, S.W. 2005. Improvements of the MODIS terrestrial gross and net primary production global data set. - Remote Sensing of Environment, 95, 164-176.

Zhao, M., Running S.W., Heinsch F.A., Nemani R.R. 2011. MODIS-derived terrestrial primary production. - Ramachandran, B., Justice, C.O., Abrams, M.J. (eds.). Land Remote Sensing and Global Environmental Change: NASA's Earth Observing System and the Science of ASTER and MODIS. New York, Springer-Verlag, 635660. 


\title{
Kiirguse kasutamise efektiivsuse põhimõttele tuginevate taimkatte neto-produktsiooni hinnangute analüüs muldkatte fütoproduktiivsuse mudeli abil
}

\author{
Mait Lang, Raimo Kõlli, Maris Nikopensius, Tiit Nilson, Mathias Neumann ja \\ Adam Moreno
}

Kokkuvõte

Taimkatte neto-produktsiooni (NPP) pidev seire on oluline nii elukeskkonda mõjutavate tegurite kui ka muldkatte produktiivsuse jälgimiseks. Metsade fütoproduktsiooni saab hinnata statistilise valimhinnanguga kogutud andmeid kasutades (statistiline metsainventuur) (Tomppo et al., 2010; GFOI, 2013; Bontemps \& Bouriaud, 2014) või teisalt satelliitkaugseire abil mõõdetud fotosünteetiliselt aktiivse kiirguse suhtelise neeldunud osa (fAPAR), valguse kasutamise tõhususe (LUE) ja fotosünteesi piiravate tegurite (veeauru defitsiit ja õhutemperatuur) kaudu (Zhao et al., 2005). Uuringu eesmärgiks oli kasutada Eesti mullakaardi infot satelliitseirele tuginevate NPP hinnangute analüüsimiseks. Töös kasutati 2914 vaatlusala, mis vastasid ristkoordinaatide süsteemis $500 \times 1000 \mathrm{~m}$ suurustele MODIS NPP produkti pikslitele (joonis 1) ja olid 1) üle $30 \mathrm{~km}$ Läänemere rannikust sisemaa suunas, 2) kaetud vähemalt $75 \%$ ulatuses metsaeraldiste andmetega, 3) alla $10 \%$ pindalast mõjutatud tugevatest häiringutest alates 2001. aastast, ja 4) metsandike piiridest $1 \mathrm{~km}$ seespool.

Mullakaardi andmebaasi igale mullakontuurile arvutati Kõlli (1988) töös joonisel 3.2 esitatud mudeli abil taimkatte maapealse osa potentsiaalse fütoproduktiivsuse (SPP) hinnang. Gleimuldadel kasutati turba tüsedusest sõltuvat korrektsiooni (1) ja lisaks rakendati peenliiva ja liiva lõimisega leetjatel gleimuldadel faktorit 0,85 . Taimkatte maa-aluse osa NPP hinnang lisati faktori 1,2 abil, mis vastab keskmiselt parasvöötme keskealistele ja vanematele metsadele IPCC (2006) järgi ja saadi mulla viljakusele tuginev $N P P_{\mathrm{SPP}}$. Metsaregistri andmetest võetud puidu juurdekasvul põhineva NPP hinnangu (NPP FIDB $_{\text {) arvuta- }}$ miseks kasutati biomassi laiendustegurit $B C E F i=0,72$ (IPCC 2006) ja lisati ka varise hinnangud $(2,3)$. Peenjuurte juurdekasvu hinnang võeti võrdseks varise toodanguga. Mullakaardi ja metsaregistri andmetele tuginevad NPP hinnangud olid omavahel loogilises kooskõlas (joonised 2 ja 3).

Andmestike (tabel 1) analüüsiks kasutati regressioonmudelit (4), mille argumentideks olid Eenmäe et al. (2011) kirjeldatud Eesti territoriaalsed tsoonid $\left(Z_{\text {DAO }}\right)$ (tekivad globaalsetes NPP hinnangutes väikese ruumilahutusega ilmastikuandmete tõttu), $N P P_{\text {SPP }}$ ja metsaregistri andmetest arvutatud okasmetsa osakaal K (\%). Mudeli (4) parameetrite hinnangutest (tabel 2) selgus, et $N P P_{\text {FIDB }}$ suureneb Eestis läänest itta nagu $N P P_{\text {SPP }}$ ja kahaneb koos okaspuistute osakaalu kasvuga, sest Eestis domineerivad väheviljakatel muldadel enamasti männikud (madalsoodes siiski ka lehtpuupuistud). Kõikide LUE-tüüpi mudelite puhul ilmnes selgelt hinnangute oluliselt kitsam haare IQR (tabel 2) võrreldes mulla potentsiaalse fütoproduktiivsusega. Globaalsetele ilmaandmetele tuginevate $N P P_{\text {NTSG }}$ ja $N P P_{\text {NTSG_GPP }}$ seos $N P P_{\text {SPP }}$ väärtustega oli äraspidine ja tähtsaimaks teguriks osutus hoopis $Z_{\text {DAO }}$. Ruumiliselt parema lahutusega ilmaandmete kasutamise tulemusena Neumann et al. (2016) saadud $N P P_{\text {EURO }}$ kasvas läänest ida suunas nagu ka $N P P_{\mathrm{SPP}}$. $N P P_{\text {EURo }}$ puhul oli NPP aga saadud lehepinnaindeksiga seotud kasvu- ning säilitushingamise arvestamise kaudu fotosünteesi üldisest produktist (GPP). Arvatavasti nende lisaparameetrite vigade tõttu jäi 
$N P P_{\text {EURO ja }} N P P_{\text {SPP }}$ seos siiski negatiivseks. Kokkuvõtteks järeldati, et rutiinselt toodeKõige sisukama kooskõla mulla fütopro- tavate üleilmsete NPP hinnangute vigade duktiivsusega andsid Eesti andmetel põ- vähendamiseks tuleks võtta kasutusele hinevale maakattekaardile ja kõrge ruu- lokaalselt parandatud maakattekaardid milise lahutusega ilmaandmetele tuginev ja suurendada fAPAR-i mõõtmistäpsust. Nilson et al. (2012) töös avaldatud NPP Eesti mullakaart ja metsade takseerkirhinnangud (tabel 1), mille sisendiks kasu- jeldused osutusid unikaalseteks referenttatud fAPAR-i ja NPP SPP vahel oli samuti sandmestikeks satelliitseirele tuginevate positiivne korrelatsioon (joonis 4, tabel 2). NPP hinnangute headuse analüüsimisel. 